\title{
JNK2 contains a specificity-determining region responsible for efficient c-Jun binding and phosphorylation
}

\author{
Tuula Kallunki, ${ }^{1}$ Bing Su, ${ }^{1}$ Igor Tsigelny, ${ }^{2}$ Hayla K. Sluss, ${ }^{3}$ Benoit Dérijard, ${ }^{3}$ George Moore, \\ Roger Davis, ${ }^{3}$ and Michael Karin ${ }^{1,4}$ \\ Departments of Pharmacology ${ }^{1}$ and Chemistry, ${ }^{2}$ Center for Molecular Genetics, Program in Biomedical Sciences, School \\ of Medicine, University of California, San Diego, La Jolla, California 92093-0636 USA; ${ }^{3}$ Howard Hughes Medical Institute, \\ Program in Molecular Medicine, Department of Biochemistry and Molecular Biology, University of Massachusetts Medical \\ School, Worcester, Massachusetts 01601 USA
}

The transcriptional activity of c-Jun is augmented through phosphorylation at two sites by a c-Jun amino-terminal kinase (JNK). All cells express two distinct JNK activities, 46 and $55 \mathrm{kD}$ in size. It is not clear which of them is the more important c-Jun kinase and how they specifically recognize c-Jun. The 46-kD form of JNK was identified as a new member of the MAP kinase group of signal-transducing enzymes, JNK1. Here, we report the molecular cloning of the 55-kD form of JNK, JNK2, which exhibits $83 \%$ identity and similar regulation to JNK1. Despite this close similarity, the two JNKs differ greatly in their ability to interact with c-Jun. JNK2 binds c-Jun $\sim 25$ times more efficiently than JNK1, and as a result has a lower $K_{\mathrm{m}}$ toward c-Jun than JNK1. The structural basis for this difference was investigated and traced to a small $\beta$-strand-like region near the catalytic pocket of the enzyme. Modeling suggests that this region is solvent exposed and therefore is likely to serve as a docking site that increases the effective concentration of c-Jun near JNK2. These results explain how two closely related MAP kinases can differ in their ability to recognize specific substrates and thereby elicit different biological responses.

[Key Words: JNK; MAP kinase; phosphorylation; substrate specificity]

Received September 19, 1994; revised version accepted November 4, 1994.

The trans-activation potential of the c-Jun proto-oncoprotein is augmented by phosphorylation at Ser-63 and -73 (Binétruy et al. 1991; Pulverer et al. 1991; Smeal et al. 1991). Phosphorylation of these residues is stimulated by transforming oncoproteins (Binétruy et al. 1991; Smeal et al. 1991, 1992), growth factors (Smeal et al. 1992), UV irradiation (Devary et al. 1992), and antigenic activation of $T$ cells (Su et al. 1994). In vitro, Ser-63 and -73 are specifically phosphorylated by two protein kinases, 46 and $55 \mathrm{kD}$ in size, that bind to the amino-terminal activation domain of c-Jun, termed JNKs (Hibi et al. 1993; Minden et al. 1994). No other protein kinases were found to phosphorylate these sites (Hibi et al. 1993; Minden et al. 1994). The JNKs are strongly activated following UV irradiation and more modestly by Ha-Ras expression (Hibi et al. 1993; Dérijard et al. 1994). Molecular cloning identified the $46-\mathrm{kD}$ form of JNK as a novel MAP kinase, termed JNK1, displaying $\sim 40 \%$ sequence identity to other MAP kinases, including ERK1 and ERK2 (Dérijard at al. 1994). Despite their ability to use phosphoacceptor sites with primary structure similar to the JNK phospho-

\footnotetext{
${ }^{4}$ Corresponding author.
}

rylation sites (Davis 1993), ERK1 and ERK2 do not phosphorylate Ser-63 and -73 and instead phosphorylate c-Jun at Ser-243 near its carboxyl terminus (Alvarez et al. 1991; Minden et al. 1994). c-Jun provides a good example for the distinct substrate specificity of MAP kinases, whose minimal consensus phosphorylation site is either Ser-Pro or Thr-Pro (Davis 1993). This group of protein kinases occupies an important and critical role in cellular signal transduction, as they convert extracellular stimuli to specific regulatory events affecting the pattern of gene expression, most likely through phosphorylation of specific transcription factors (Ammerer 1994; Karin 1994). Despite the rapidly accumulating knowledge regarding the regulatory pathways responsible for MAP kinase activation and their phenotypic effects on genetically dissectable organisms, such as yeast (Ammerer 1994) and Drosophila (Brunner et al. 1994; O'Neill et al. 1994), the mechanisms responsible for their substrate specificity are currently unknown.

More recently, a murine homolog of JNK1, termed SAPK $\gamma$, was cloned as well as three related proteins SAPK $\alpha$ I, SAPK $\alpha$ II and SAPK $\beta$ (Kyriakis et al. 1994). However, the involvement of the individual SAPKs in 
c-Jun phosphorylation or their regulation was not determined. It is not clear which of the JNKs is directly involved in regulation of c-Jun activity and whether individual enzymes exhibit any functional or regulatory differences. Here, we describe the molecular cloning of the $55-\mathrm{kD}$ form of human JNK, JNK2, which is probably the human homolog of SAPKaII. The two JNKs are closely related and similarly regulated. Despite the close similarity, JNK2 displays considerably higher affinity toward c-Jun than JNK1 does. The molecular basis for this difference was investigated through generation of JNKl/ JNK2 chimeras and was traced to a small region located next to the catalytic pocket of the enzyme. Modeling suggests that this region is solvent exposed and thus may serve as a substrate docking site responsible for increasing the effective substrate concentration next to the JNK2 catalytic site. Consistent with this difference, overexpression of wild-type JNK2 but not JNK1 potentiates expression of a c-Jun-dependent reporter gene. Therefore, JNK2 is likely to be responsible for c-Jun activation, whereas JNK1 may be involved in regulation of other substrates. These structural and functional differences between two otherwise similar MAP kinases can explain why members of this group exhibit biological specificity even though their primary sequence specificities for phosphate transfer are very similar to one another.

\section{Results}

\section{Molecular cloning of INK2}

By in-gel kinase assays we have identified two protein kinases, 46 and $55 \mathrm{kD}$ in size, termed JNKs, that bind to the c-Jun activation domain and phosphorylate it on Ser63 and -73 (the latter being the major phosphoacceptor site; Hibi et al. 1993). The 46-kD form of JNK was shown to be a novel MAP kinase, termed JNK1 (Dérijard et al. 1994). Because the two JNK activities are similarly regulated (Hibi et al. 1993; Su et al. 1994), they are likely to be structurally related. Thus, we screened a Jurkat T-cell lymphoma cDNA library with a JNK1 cDNA probe to identify a related species that may encode the $55-\mathrm{kD}$ form of JNK. One of the cDNA clones thus identified, with an insert size of $3.3 \mathrm{~kb}$, has turned out to encode a protein kinase that is $83 \%$ identical in its primary structure to JNK1 but only $39 \%$ identical to ERK2 (Fig. 1A). A cDNA clone encoding the same protein was also isolated from a HeLa cell library. No other cDNAs that exhibit considerable similarity to JNKl were isolated despite extensive screening of both libraries. Importantly, the open reading frame of the newly identified cDNA specifies a 424 amino acid polypeptide that is larger than JNK1 1385 amino acids in length). Like JNKl, the new protein, termed INK2, contains a Thr-Pro-Tyr sequence at position $183-185$. This sequence is functionally and struc-
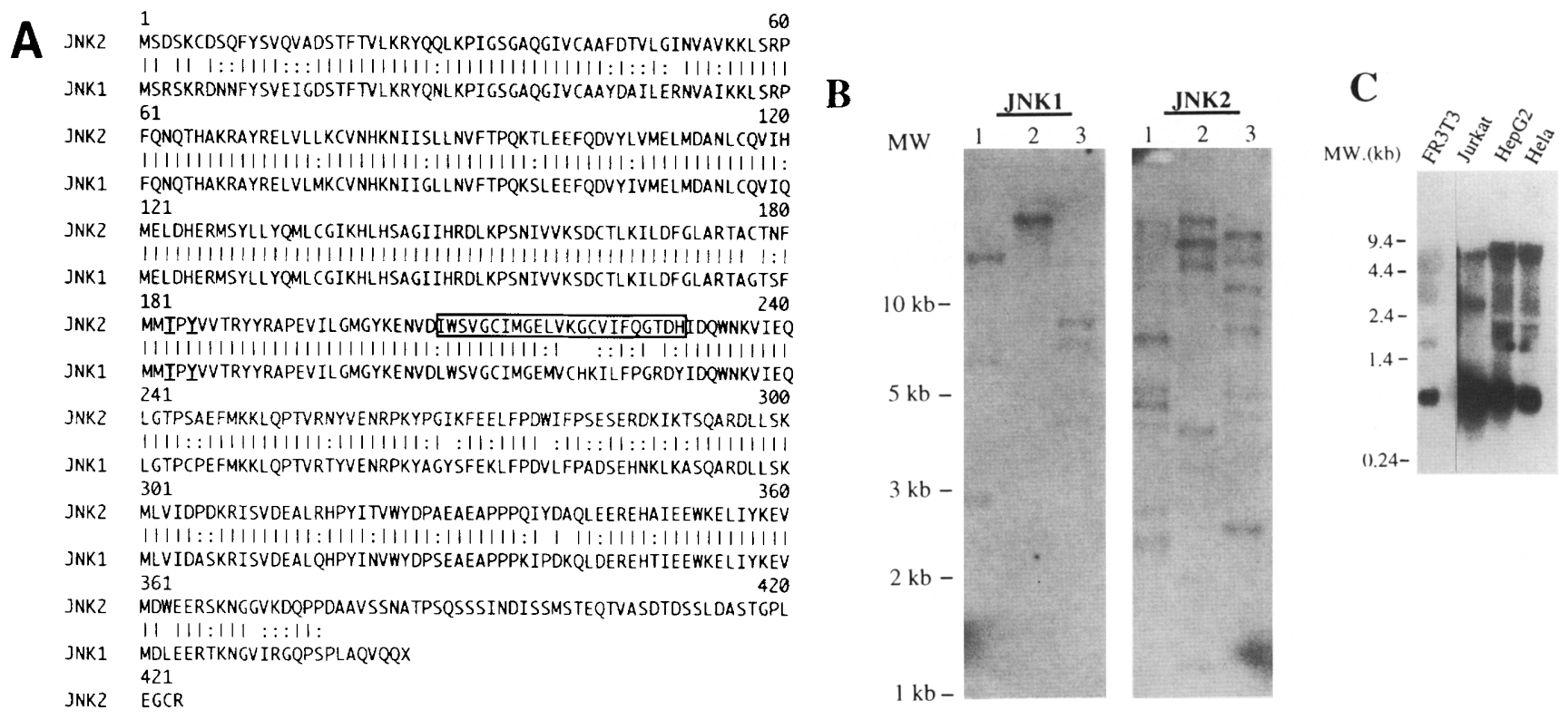

Figure 1. Molecular characterization of INK2. (A) Comparison of JNK2 and INK1 amino acid sequences. The Thr and Tyr residues that are required for activation of JNK1 and are conserved in JNK2 are underlined, and the region that determines the efficient binding of JNK2 to c-Jun (see below) is boxed. The JNK2 nucleotide sequence has been deposited to GenBank and is available under accession number U09759. $(B)$ Southern blot analysis. Human genomic DNA (10 $\mu \mathrm{g})$ was digested with either EcoRI (lane 1), BamHI (lane 2), or HindIII (lane 3), separated on an agarose gel, and transferred to a Nytran-nylon membrane (Schleicher \& Schuell). The membranes were hybridized at $65^{\circ} \mathrm{C}$ for $16 \mathrm{hr}$ with full-length JNK1 and JNK2 cDNA probes, washed extensively at room temperature with $1 \times$ SSC, $0.1 \%$ SDS, followed by $0.2 \times \mathrm{SSC}, 0.1 \%$ SDS, at $65^{\circ} \mathrm{C}$. The migration positions of molecular mass markers are shown. $|C|$ Northern blot analysis of JNK2 expression. Samples of total cellular RNA $(5 \mu \mathrm{g})$ isolated from FR3T3, Jurkat, HepG2, and HeLa cells were separated in a $1.5 \%$ agarose gel transferred to Zetabind membrane (Cuno), hybridized with JNK2 cDNA probe for $16 \mathrm{hr}$ at $65^{\circ} \mathrm{C}$, and washed extensively at $65^{\circ} \mathrm{C}$ with $0.2 \times \mathrm{SSC}, 0.1 \%$ SDS. 
turally equivalent (Dérijard et al. 1994) to the Thr-GluTyr sequence, which contains the activating phosphorylation sites of ERK1 and ERK2 (Ahn et al. 1992). Southern blot analysis (Fig. 1B), as well as the scattered sequence differences between JNK1 and JNK2, indicated that they are products of different genes. Northern hybridization (Fig. 1C; data not shown) indicates that JNK2 is expressed in many cell types. As observed for JNK1 (Dérijard et al. 1994), several JNK2 transcripts were detected. The same transcript heterogeneity was revealed by analysis of poly $(\mathrm{A})^{+}$RNA (data not shown). The abundant transcript that is $<1 \mathrm{~kb}$ in length is likely to represent an alternatively spliced form of JNK2 that can potentially code for truncated protein of unknown functional significance (K. Yoshioka, unpubl.).

\section{INK1 and INK2 are identically regulated}

To examine whether JNK2 is a functional c-Jun aminoterminal kinase, we transfected Jurkat cells with an expression vector encoding JNK2 tagged with the HA epitope (Wilson et al. 1984) at its amino terminus. Because both forms of JNK are strongly activated following UV irradiation (Hibi et al. 1993), the transfected cells were UV irradiated prior to preparation of lysates. Immune complex kinase assays, using GST c-Jun(1-79) as a substrate, revealed that the anti-HA antibody precipitated a 55-kD c-Jun kinase only from cells transfected with the HA-JNK2 vector (Fig. 2A). No such activity was present in control immune complexes generated with an anti-CD3 antibody. To determine whether JNK2 specifically phosphorylated the amino-terminal sites of c-Jun, we phosphorylated full-length recombinant $\mathrm{c}$-Jun with immunopurified HA-JNK2 and subjected it to two-dimensional tryptic phosphopeptide mapping (Boyle et al. 1991). The resulting phosphopeptides (Fig. 2B) were identical in their mobilities to the $\mathrm{X}$ and $\mathrm{Y}$ phosphopeptides, whose abundance is increased following in vivo INK activation (Devary et al. 1992; Su et al. 1994), and phosphopeptides $\mathrm{T} 1$ and $\mathrm{T} 2$, which correspond to secondary JNK phosphorylation sites (Hibi et al. 1993; Dérijard et al. 1994). The same phosphopeptides were generated by phosphorylation of c-Jun with HA-JNK1. As shown previously (Smeal et al. 1991), phosphopeptides X and Y correspond to phosphorylation of c-Jun at Ser-73 and Ser63 , respectively.

We used the immune complex kinase assay to compare the regulation of transiently expressed JNK1 and JNK2 to the endogenous 46- and $55-\mathrm{kD}$ forms of JNK, probed by an in-gel kinase assay (Kameshita and Fujisawa 1989). The transiently expressed JNK1 and JNK2 were regulated very similarly to the endogenous forms of JNK in both HeLa and Jurkat cells (Fig. 2C). Both enzymes were rapidly activated in response to a variety of physiological (growth factors and cytokines) and stressful stimuli. The most potent activators of JNKI and JNK2 were UV irradiation (50- to 90-fold) and a low concentration $(50 \mathrm{ng} / \mathrm{ml})$ of the protein synthesis inhibitor anisomycin (50- to 200-fold). At this concentration, anisomycin does not inhibit protein synthesis but induces immediate early genes, including c-jun (Edwards and Mahadevan 1992) and activates protein kinases with sizes identical to those of JNK1 and JNK2 (Cano et al. 1994). This effect was not seen with another protein synthesis inhibitor, cycloheximide, which is a less effective activator of JNK1 and JNK2 (7- to 14-fold), even at fully inhibitory concentrations. Another stressful stimulus, heat shock, led to weak activation (three- to fourfold) of these enzymes. Modest activation of JNK1 and JNK2 was observed following treatment of HeLa cells with epidermal growth factor (EGF; 3- to 10-fold) or tumor necrosis factor- $\alpha$ (TNF $\alpha$; 6 - to 16 -fold). Together, the two factors synergistically activated both JNK1 and JNK2 (25- to 60fold). As described (Su et al. 1994), JNK1 and JNK2 were synergistically activated (30- to 60 -fold) by costimulation of Jurkat cells with the phorbol ester TPA and the calcium ionophore A23187. Whereas treatment with TPA alone gave rise to weak JNK1 and JNK2 activation (five- to sevenfold), treatment with A23187 alone did not activate either enzyme (data not shown).

\section{JNK2 has higher affinity to c-Jun}

The two forms of JNK were identified by their ability to bind the amino-terminal activation domain of c-Jun (Hibi et al. 1993). The binding site is located between amino acids 30 and 60 of c-Jun and its integrity is important not only for JNK binding in vitro but also for phosphorylation of c-Jun and enhancement of its transcriptional activity in vivo (Hibi et al. 1993). To investigate whether JNK2 binds c-Jun through the same site, we incubated immunopurified HA-INK2 with glutathioneagarose beads coated with different GSTc-Jun fusion proteins that either contain or lack an intact JNK-binding site (Hibi et al. 1993). As described (Hibi et al. 1993; Dérijard et al. 1994), the incubations were carried out in the absence of ATP, the beads were washed extensively, and JNK binding was assayed by addition of $\left[\gamma^{-{ }^{32}} \mathrm{P}\right] \mathrm{ATP}$ and phosphorylation of the c-Jun moiety of the immobilized fusion protein (Fig. 3A). Like JNK1, JNK2 bound to GSTc-Jun(1-223), GSTc-Jun(1-79), and GSTc-Jun(1-223; Ala-63/73). (The latter is a mutant in which Ser-63 and -73 , which are not required for JNK binding, were substituted by Ala residues. This mutant is phosphorylated on secondary sites (Hibi et al. 1993)]. JNK2 also bound to the chicken (ch) c-Jun amino-terminal domain [GSTch.cJun(1-144)). JNK2 did not bind to GSTc-Jun(43-223) or GSTch.v-Jun. The latter two proteins lack intact JNKbinding sites (Hibi et al. 1993).

To examine the binding of JNK1 and JNK2 to c-Jun by a more conventional assay, we passed lysates of HAJNK1- or HA-JNK2-expressing Jurkat cells, containing similar amounts of either enzyme, through glutathioneagarose-GSTc-Jun(1-79) columns and, after extensive washing, eluted the bound proteins with buffer containing SDS. The input and bound fractions were separated on a denaturing gel and analyzed by immunoblotting with anti-HA antibody (Fig. 3B). Approximately $10 \%$ of the HA-JNK2 input bound the affinity resin, whereas $<1 \%$ of the HA-INK 1 input was retained on the column. 
A

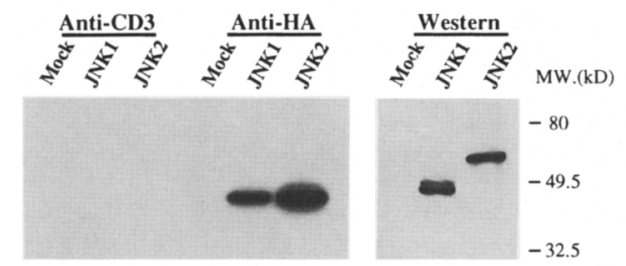

B

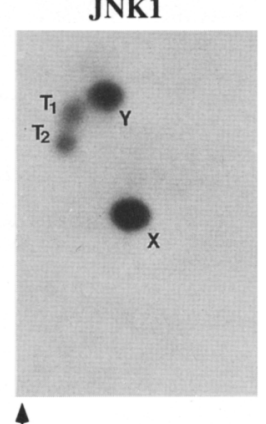

JNK2

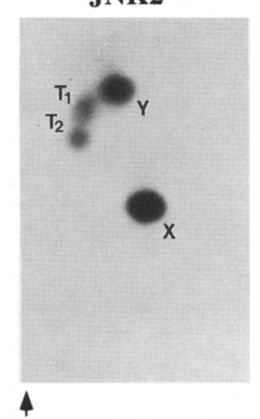

C
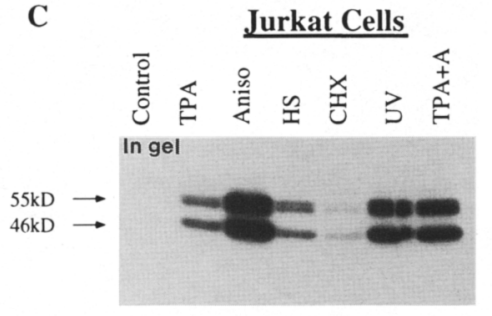

JNK1

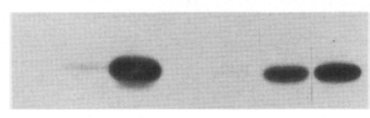

JNK2

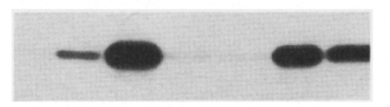

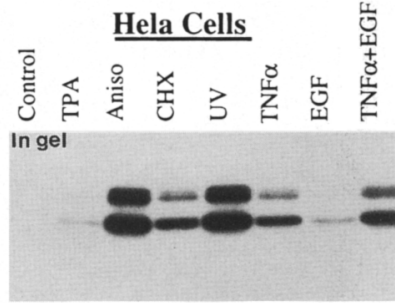
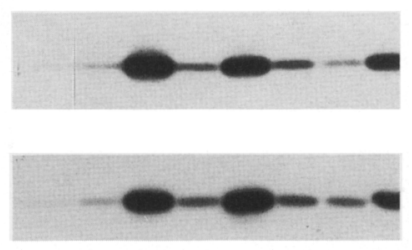

Figure 2. JNK2 corresponds to the $55-\mathrm{kD}$ form of JNK. (A) JNK2 is a 55-kD c-Jun kinase. Jurkat cells were transfected with either empty expression vector (pSR $\alpha 3), \mathrm{HA}-\mathrm{JNK}$ l or $\mathrm{HA}-\mathrm{JNK} 2$ expression vectors. Forty hours later the cells were exposed to $40 \mathrm{~J} / \mathrm{m}^{2}$ of UV-C. After $20 \mathrm{~min}$ the cells were washed with PBS and lysed in the presence of proteinase inhibitors. Half of the lysates were incubated with monoclonal anti-CD3 antibody and the other half with monoclonal anti-HA antibody. The immune complexes were suspended in $30 \mu \mathrm{l}$ of kinase buffer containing $1 \mu \mathrm{M}$ cold ATP, $10 \mu \mathrm{Ci}$ of $\left[\gamma^{-}{ }^{32} \mathrm{P}\right] \mathrm{ATP}$, and $0.5 \mu \mathrm{g}$ of GSTc-Jun(1-79), as a substrate. After $20 \mathrm{~min}$ at $30^{\circ} \mathrm{C}$, the reactions were terminated by boiling in SDS-sample buffer; they were then separated on a $10 \%$ SDS-polyacrylamide gel and visualized by autoradiography. These results are shown in the left-hand panel. Expression of HA-JNK1 and HA-INK2 was monitored by Western blot analysis of the same lysates using the anti-HA antibody and the ECL detection system (Amersham). These results are shown in the right-hand panel. $(B)$ JNK2 phosphorylates the same sites on c-Jun as JNK1. HA-JNK1 and HA-JNK2 were immunoprecipitated from transiently transfected Jurkat cells following UV irradiation as described above. The immune complexes were washed thoroughly and used to phosphorylate recombinant full-length c-Jun protein in vitro. After separation by SDSPAGE, the phosphorylated c-Jun bands were transferred to a nitrocellulose membrane and subjected to two-dimensional tryptic peptide mapping. The phosphorylated peptides $(\mathrm{X}, \mathrm{Y}, \mathrm{T} 1$, and $\mathrm{T} 2)$ are marked. $(C)$ Regulation of transiently expressed JNK1 and JNK2 and the endogenous 46- and 55-kD forms of JNK. Jurkat and HeLa cells were transfected with either HA-JNK1 or HA-JNK2 expression vectors. Forty hours after transfection, the cells were exposed to $10 \mathrm{ng} / \mathrm{ml}$ of TPA, $50 \mathrm{ng} / \mathrm{ml}$ of anisomycin (Aniso), $150 \mu \mathrm{g} / \mathrm{ml} \mathrm{of}$ cycloheximide (CHX), $40 \mathrm{~J} / \mathrm{m}^{2}$ UV-C, $10 \mathrm{ng} / \mathrm{ml}$ of TPA $+1 \mu \mathrm{g} / \mathrm{ml}$ of A23187, $10 \mathrm{ng} / \mathrm{ml}$ of TNF $\alpha, 15 \mathrm{ng} / \mathrm{ml} \mathrm{of} \mathrm{EGF,} 10 \mathrm{ng} / \mathrm{ml} \mathrm{of}$ $\mathrm{TNF} \alpha+15 \mathrm{ng} / \mathrm{ml}$ of EGF or heat shock (HS) at $42^{\circ} \mathrm{C}$. After $20 \mathrm{~min}$, lysates were prepared and immune complex kinase assays were performed as described above. Phosphorylation of GSTC-Jun(1-79) by immunoprecipitated HA-JNK1 and HA-INK2 in both Jurkat and HeLa cells is shown in the two bottom panels. To examine the effect of these treatments on endogenous JNK activities, nontransfected Jurkat and HeLa cells were subjected to the same treatments and analyzed by an in-gel kinase assay using GSTc-Jun(1-79) as a substrate. These results are shown in the top panel.

Quantitation of the binding of the two INKs to GSTcJun(1-79) revealed that JNK2 bound c-Jun 25-fold more efficiently than JNK1 (Fig. 4). A similar difference was found when the binding of ${ }^{35} \mathrm{~S}$-labeled c-Jun to GSTJNK1 and GST-JNK2 was measured (data not shown). No effect of activation by anisomycin on binding of either JNK1 or JNK2 was detected (Fig. 3B). Binding was specific, as no binding of JNK2 (or JNK1; data not shown) to a glutathione-agarose-GSTch.v-Jun column could be detected.

The more efficient binding of JNK2 to c-Jun suggested that it may be a more effective c-Jun kinase than JNK1, especially at low substrate concentrations. To examine this point, we have immunopurified transiently expressed HA-JNK1 and HA-JNK2 from anisomycin-stimulated HeLa cells or UV-irradiated COS 1 cells and eluted both enzymes from the immune complex using a peptide corresponding to the HA epitope. Equal amounts of each enzyme were incubated with various concentrations of c-Jun, and the rate of c-Jun phosphorylation was quantitated. Either preparation of JNK2 was a more effective c-Jun kinase than the equivalent preparation of INK1 (Fig. 3C,D). The Michaelis constants $\left(K_{\mathrm{m}}\right)$ of JNK1 and JNK2 toward c-Jun determined by double reciprocal plots (Lineweaver-Burke), were $2500 \pm 500 \mathrm{nM}$ and $350 \pm 50 \mathrm{nM}$, respectively. Thus, at low substrate concentrations JNK2 is likely to be the predominant c-Jun amino-terminal kinase.

The structural basis for preferential c-lun phosphorylation by INK2

The marked differences between the abilities of JNK2 and JNKl to bind and phosphorylate c-Jun provided an 
Kallunki et al.

$\mathbf{A}$
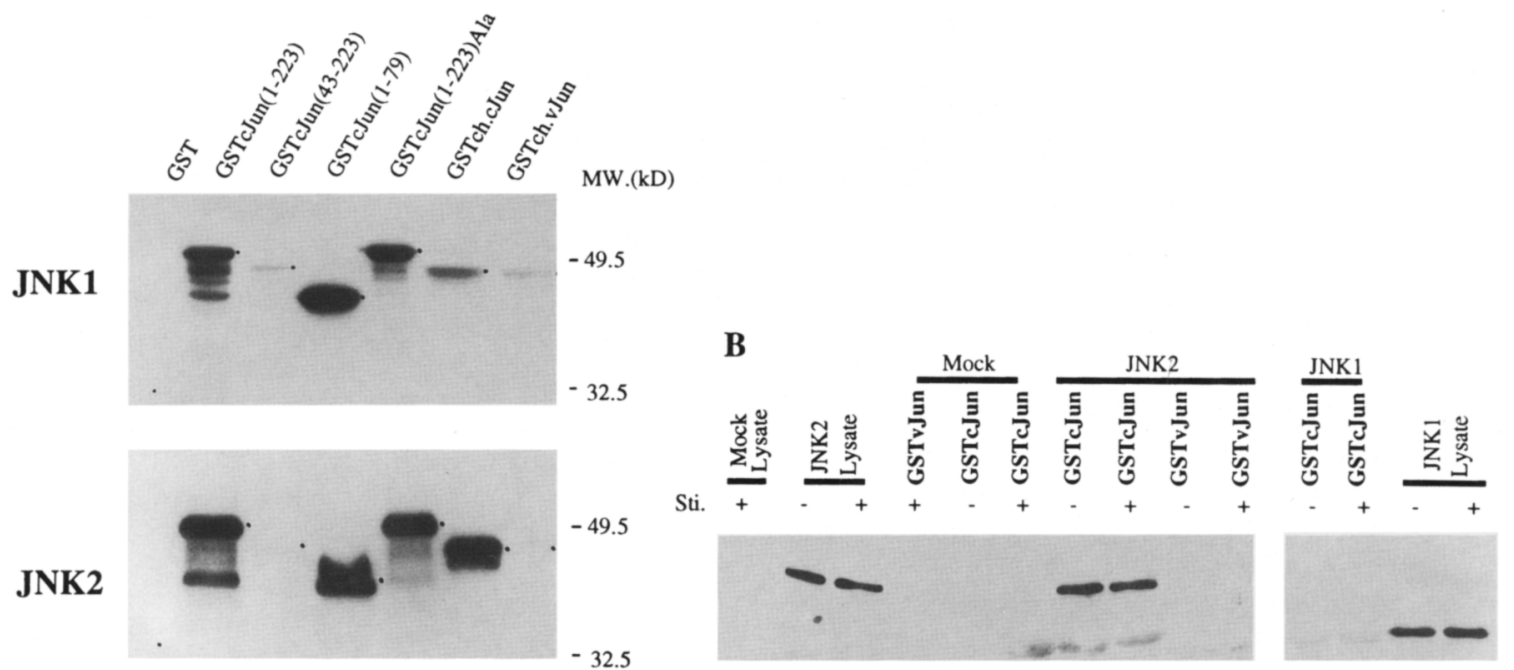

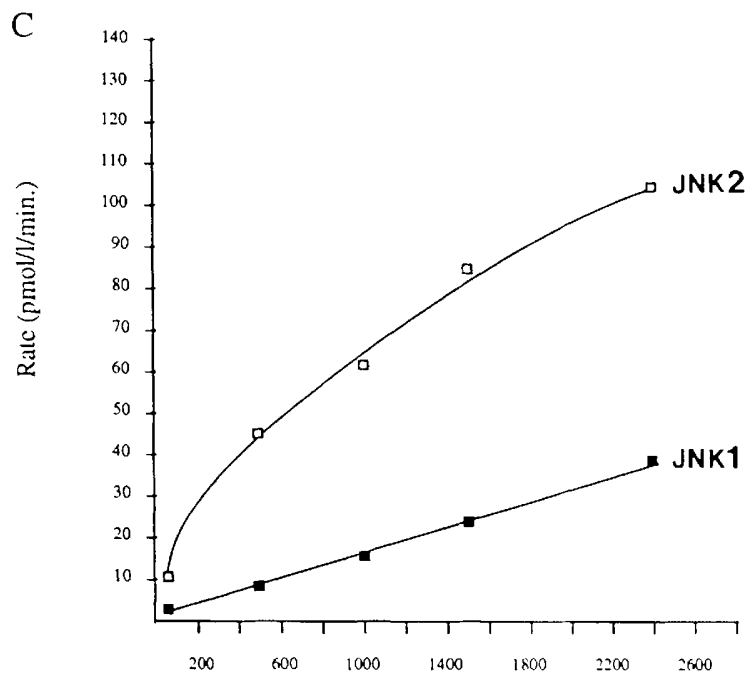

c-Jun (nmolli)
$\mathrm{D}$

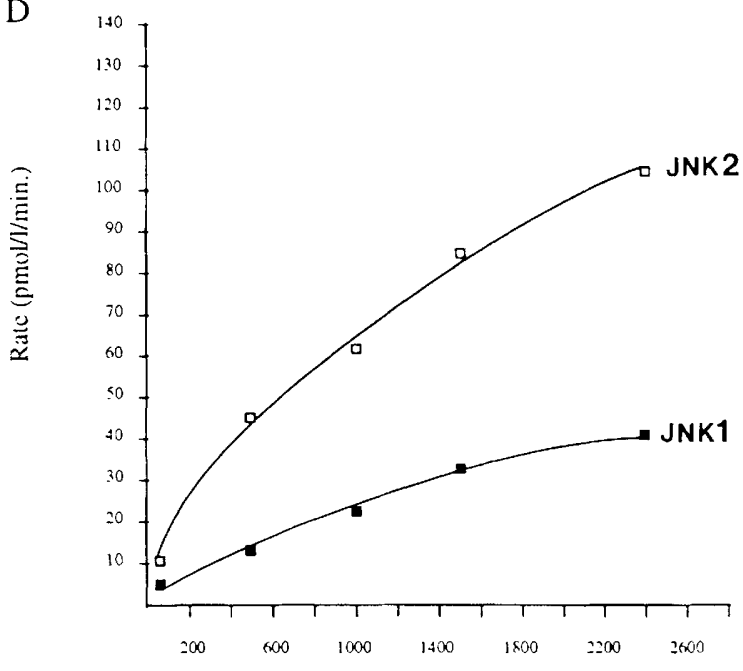

c-Jun $(\mathrm{nmol} / \mathrm{l})$

Figure 3. Binding and phosphorylation of c-Jun by JNK 1 and JNK2. $(A)$ JNK2 recognizes the same binding site as JNK1. HA-JNK1 and HA-JNK2 were isolated from transiently transfected Jurkat cells treated with $50 \mathrm{ng} / \mathrm{ml}$ of anisomycin. The immunopurified kinases were incubated with glutathione-agarose beads coated with $3 \mu \mathrm{g}$ of GST, GSTc-Jun(1-223), GSTc-Jun(43-223), GSTc-Jun(1-79), GSTc-Jun(1-223)Ala, GSTch.c-Jun(1-144), or GSTch.v-Jun. After extensive washing, the beads were incubated with $\left[\gamma^{-32} \mathrm{P}\right]$ ATP in kinase buffer for $20 \mathrm{~min}$ at $30^{\circ} \mathrm{C}$. The phosphorylation reaction was terminated by incubation in SDS-sample buffer and boiling. The phosphorylated proteins were resolved by SDS-PAGE and visualized by autoradiography. $(B)$ JNK2 binds c-Jun more efficiently than JNK1. Jurkat T-antigen cells $\left(10^{7}\right)$ were transfected with $10 \mu \mathrm{g}$ of empty expression vector (pSR $\alpha 3$; mock), or HA-JNK1 or HA-JNK2 expression vector. Forty hours later cells were either not treated $|-|$ or treated $|+|$ with $50 \mathrm{ng} / \mathrm{ml}$ of anisomycin to activate the JNKs. After $20 \mathrm{~min}$, lysates were prepared and $90 \%$ of the material was incubated with glutathione-agarose beads coated with $40 \mu \mathrm{g}$ of either GSTc-Jun(1-79) or GSTch.v-Jun. After extensive washing the bound proteins were eluted by boiling in SDS-sample buffer and separated by SDS-PAGE. Ten percent of the unfractionated lysates were separated on the same gel. The proteins were transferred to Immobilon-P membranes (Millipore), and the bound HA-JNK proteins were detected by Western blotting with anti-HA antibody and the ECL detection system. (C) Effect of c-Jun concentration on its phosphorylation by JNK1 or JNK2 isolated from HA-JNK1 and HA-JNK2-transfected UV-irradiated (UV-C $40 \mathrm{~J} / \mathrm{m}^{2}$ ) COS 1 cells. The rate of c-Jun phosphorylation (determined as described in Materials and methods) by equal amounts of either HA-JNK1 or HA-JNK2 is plotted as a function of substrate concentration. The values shown are averages of two different experiments. $(D)$ Effect of c-Jun concentration on its phosphorylation by JNK1 and JNK2 isolated from anisomycin $(50 \mathrm{ng} / \mathrm{ml})$-induced HeLa cell extracts. The rate of c-Jun phosphorylation by equal amounts of HA-JNKl and HA-JNK2 is plotted as averages of two different experiments as in $C$.

opportunity to determine the structural basis underlying the specificity of c-Jun-JNK2 interaction. Thus, we generated a series of $\mathrm{INK} 1 / \mathrm{JNK} 2$ chimeras and examined their ability to bind c-Jun and phosphorylate it. Binding to c-Jun was measured by passing extracts of HeLa cells transiently transfected with the various HA-JNK1/JNK2 


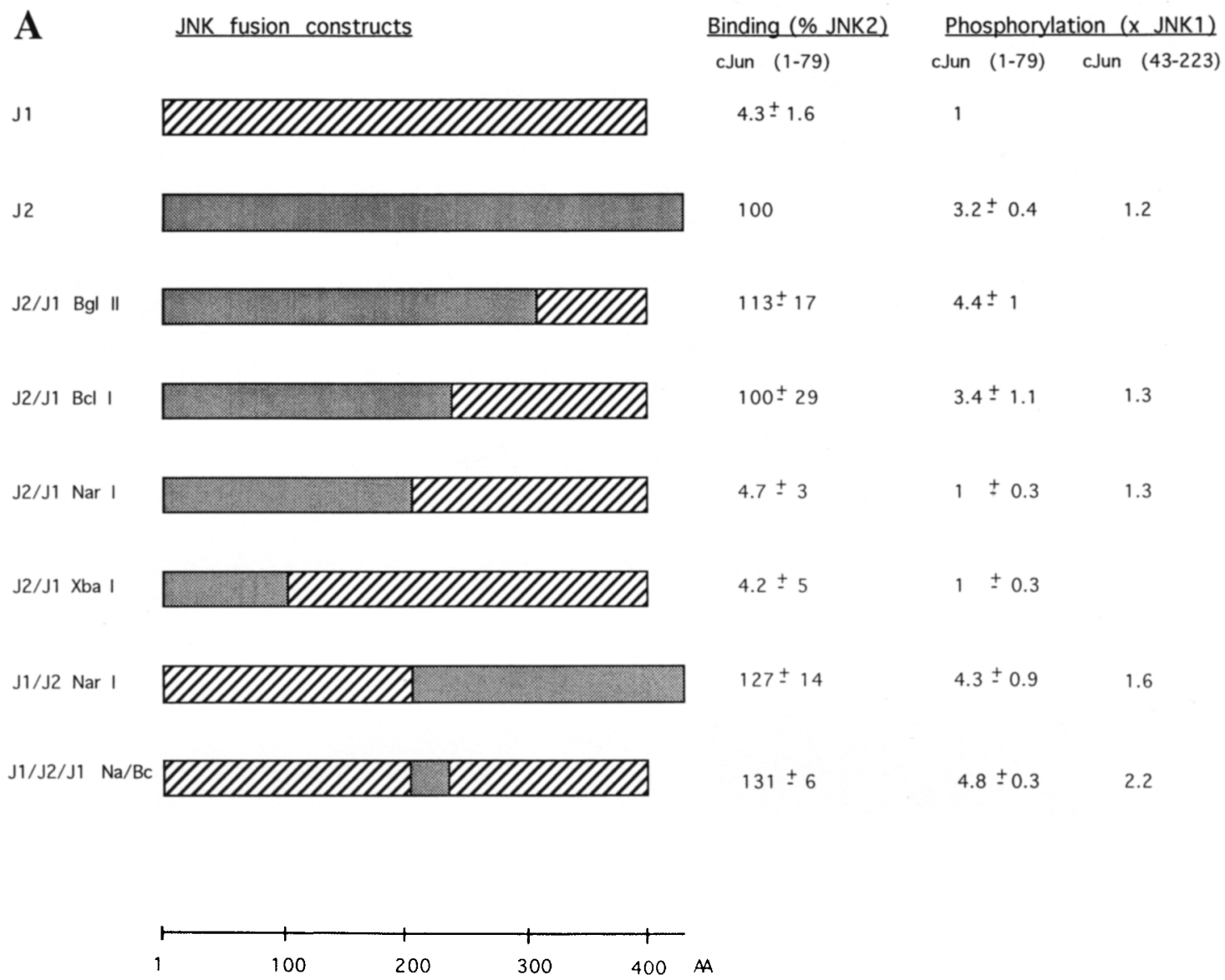

B

Figure 4. Mapping of the c-Jun binding site of JNK2. (A) A series of JNK1/JNK2 chimeras were generated using naturally occurring and artificially introduced restriction endonuclease cleavage sites in the JNK1 and JNK2 cDNAs. Schematic descriptions of the chimeras are shown at left. (Hatched bars) JNK1 sequences; (shaded bars) JNK2 sequences. The binding of each chimera to GST c-Jun $(1-79)$ affinity beads was determined as described in Materials and methods and is displayed relative to the binding efficiency of JNK2 that was chosen to be $100 \%$. Averages and standard errors of three separate experiments are shown. The abilities of the different chimeras, as well as HA-INK1 and HA-INK2 isolated from anisomycin-treated HeLa cells to phosphorylate soluble GSTc-Jun(1-79) at 150-300 nM, was determined as described in Fig. 3. The relative JNK activities are expressed using the activity of HA-JNKl as 1 . Results shown are averages and standard errors of three separate experiments. $(B)$ Binding and phosphorylation of GSTc-Jun(1-79) by selected JNK1/JNK2
constructs to a GSTc-Jun(1-79) affinity column after loading of equal Phosphorylation

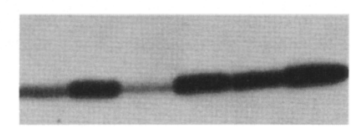
chimeras. (Top) Western blot showing binding of the different constructs to a GSTc-Jun(1-79) affinity column after loading of equal
amounts of each protein. (Bottom) The phosphorylation of soluble GSTc-Jun(1-79) by the different JNKs. For both assays, extracts of anisomycin-stimulated HeLa cells containing equal amounts of the different JNKs were used.

constructs through a GSTc-Jun(1-79) affinity column. c-Jun phosphorylation was examined by using equal amounts of transiently expressed HA-JNK1/JNK2 constructs isolated from anisomycin-activated HeLa cells and low concentrations (150-300 $\mathrm{nM}$ ) of a soluble GSTcJun(1-79) substrate. As summarized in Figure 4A, JNK2 bound GSTc-Jun(1-79) 25-fold more efficiently than JNK1 and phosphorylated c-Jun at least 3-fold more efficiently. The higher binding affinity and kinase activity of JNK2 toward c-Jun were found to be predominantly determined by a small region in its carboxy-terminal domain between amino acids 208 and 230 (boxed in Fig. 1A). In this region, JNK1 and JNK2 differ by four highly conservative amino acid substitutions /such as $\mathrm{Ile} \rightarrow \mathrm{Leu}$ ) and six less conservative and nonconservative changes. Introduction of the corresponding JNK2 sequences into this region of JNK1 increases its ability to bind c-Jun by 30 -fold and its c-Jun kinase activity by 
4.8-fold. These differences are mediated by an interaction of JNK2 with the JNK-binding site of c-Jun because a GST fusion protein lacking this site, GSTc-Jun(43-223) is phosphorylated to nearly the same extent, albeit very inefficiently, by the different JNK constructs.

To better understand the structural basis for the efficient and specific interaction of JNK2 with c-Jun, a three-dimensional model of JNK2 was constructed based on the structural homologies between the catalytic domains of cAMP-dependent protein kinase (PKA; Zheng et al. 1993), cyclin-dependent kinase 2 (CDK2; De Bondt et al. 1993), and ERK2 (Zhang et al. 1994). First, the JNK2 sequence was aligned with the sequences of all three kinases, and then using the Homology program (Biosym, 1994) and crystallographically solved structures of these protein kinases, the JNK2 model shown in Figure 5 was derived. There was a significant match in the regions including amino acids 1-243 and 293-369 of JNK2 and the published ERK2 structure (Zhang et al. 1994). The
JNK2 region that corresponds to an insert and includes amino acids 243-280 was more consistent with the CDK2 structure based on sequence alignment. The position of the entire insert was modeled on the basis of the general position of the insert in CDK2. The region that corresponds to amino acids 280-293 was further modeled using the fragment generator feature of the Homology program and was chosen as the lowest energy structure. As highlighted in the models shown in Figure 5, A and $B$, the region responsible for the specific and efficient interaction between JNK2 and c-Jun appears to form an extended chain that protrudes below the region involved in binding of the phosphoacceptor peptide and its phosphorylation. In this model the segment containing His230 is in close proximity to Thr-183 and Tyr-185, whose phosphorylation mediates JNK activation (Dérijard et al. 1994). Asp-229, Arg-189, and Arg-192 could be involved in strong electrostatic interactions and, on the basis of the PKA structure, are likely to be involved in binding of
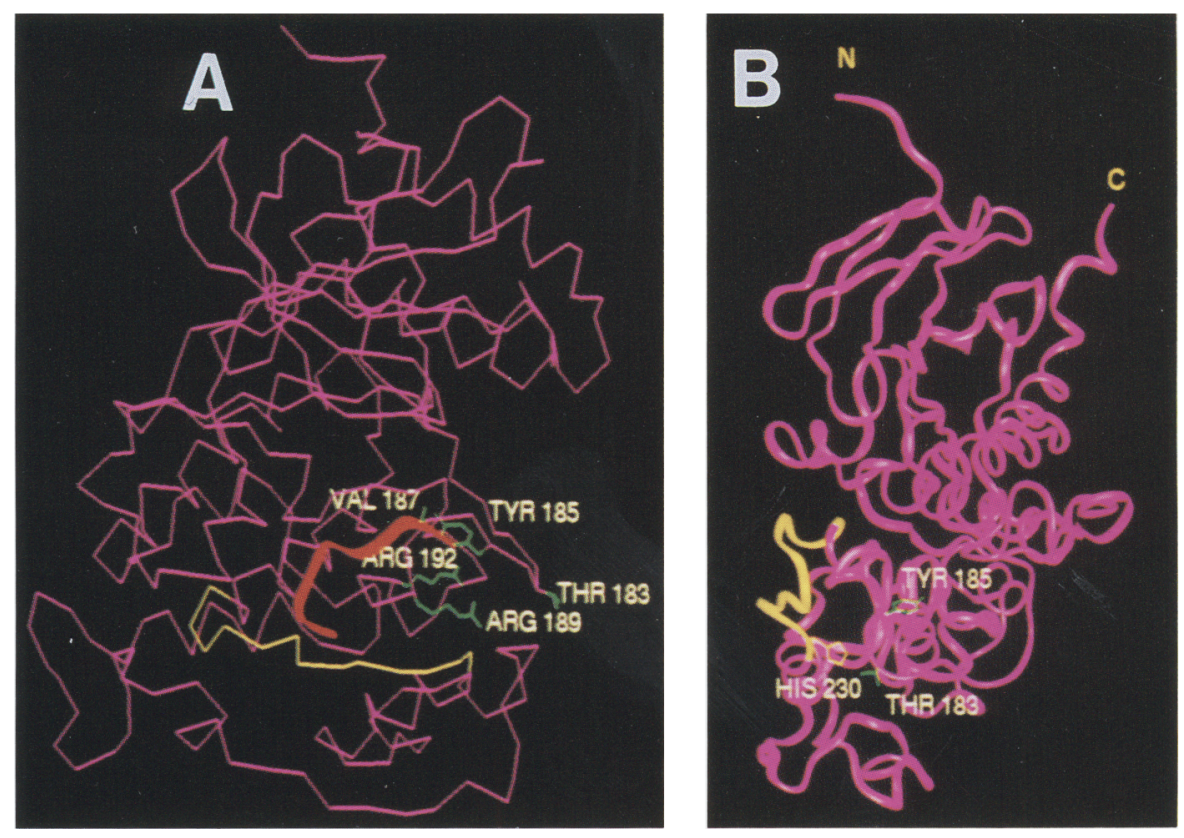

Figure 5. Structural models of JNK2 and the primary structure of its specificity-determining region. $(A \mid \mathrm{C}-\alpha$ carbon trace of the JNK2 model. The yellow tracing indicates the region found to confer high-affinity c-Jun binding and efficient c-Jun phosphorylation. Functionally important residues are indicated in green, and a putative phosphoaccepting peptide, modeled after the PKA phosphoaccepting peptide is shown as a red ribbon. In this view the amino-terminal lobe is at the top and the specificity-determining region protrudes toward the reader. $(B)$ A ribbon diagram of the JNK2 model. The specificity-determining region is shown in yellow. This view is tilted by $\sim 90^{\circ} \mathrm{C}$ relative to the view shown in $A$. (C) Sequence alignment of amino acids 208-230 of JNK2, which include the specificity-determining region, with sequences of other mammalian and yeast MAP kinases, as well as CDK2. In this alignment a three amino acid insertion (MAE) located after Ile-214 in SAPKaII (Kyriakis et al. 1994) is marked by arrowhead. With the exception of this insert, the specificity-determining region of JNK2 is full conserved in SAPK $\alpha$ II and most likely comprises residues $208-230$, as suggested by this alignment. 
the phosphoaccepting peptide (Zheng et al. 1993). The proximity of His-230 to both the positively charged Arg189 and Arg-192 and the negatively charged Asp-229 should make it very sensitive to $\mathrm{pH}$ changes or substitutions of these charged residues. Whereas the precise orientations of this region in the insert to the core obviously requires a crystal structure of JNK2 itself, the general proximity of the specificity-determining region to the active site cleft is nevertheless independent of whether CDK2 or MAPK structures are used for its modeling.

Sequence alignment of various MAP kinases, as well as $\mathrm{CDK} 2$, indicates that the specificity-determining region is unique to JNK2 and SAPK $\alpha$ II, which therefore is its murine homolog (Fig. 5C). Interestingly, in four of the six positions where it differs considerably from JNK2, JNKl contains residues that are highly conserved among MAP kinases. With the exception of ERK1 and ERK2, no two MAP kinases exhibit complete sequence identity throughout this region.

\section{In vivo effects of INK on C-Iun transcriptional activity}

To test which protein kinase is more likely to modulate c-Jun activity in vivo, we cotransfected the reporter plasmid -79jun-LUC, containing the c-Jun-responsive c-jun promoter (Angel et al. 1988), with expression vectors containing either wild-type or kinase-defective forms of JNK1 and JNK2 into Jurkat cells. As stimulation of Jurkat cells with TPA results only in partial JNK activation (Su et al. 1994), we reasoned that elevation of the intracellular level of the effective JNK should augment the weak activation of the c-jun promoter by TPA /Su et al. 1994). Activation of the c-jun promoter correlates well with changes in amino-terminal c-Jun phosphorylation (Devary et al. 1992; Su et al. 1994). Whereas cotransfection of -79iun-LUC with a JNK1 expression vector into Jurkat cells did not potentiate its weak induction/threefold above baseline) by TPA, coexpression of wild-type JNK2 resulted in twofold potentiation, leading to sixfold induction (Fig. 6A). Cotransfection of the inactive JNK1(T183A;Y185F) mutant [JNK1(APF)], whose activating phosphorylation sites were replaced by nonphosphorylatable residues (Dérijard et al. 1994), had an insignificant effect on -79jun-LUC expression. In contrast, cotransfection of the equivalent JNK2 mutant [JNK2(APF)] resulted in a $30 \%$ decrease in -79iun-LUC expression. An even greater decrease (twofold) in -79iunLUC expression was produced by transfection of JNK2 (G35E) mutant (TJ-1), in which a conserved Gly residue involved in ATP binding (Hanks et al. 1988), is substituted by a Glu residue. None of the JNK expression vectors affected expression of an ACT-LUC reporter, containing the $\beta$-actin promoter (Fig. 6A). Because the c-jun TRE appears to be recognized by a c-Jun:ATF2 heterodimer (van Dam et al. 1993) and recent evidence indicates that ATF2 activity is also stimulated by JNKmediated phosphorylation (Gupta et al. 1994), we examined the effects of JNK1 and JNK2 on c-Jun transcriptional activity using a more specific assay. A GAL4 responsive reporter was cotransfected into HeLa cells with a GAL4-c-Jun (1-223) construct encoding the GAL4 DNA-binding domain fused to the c-Jun activation domain. When a JNK2 expression vector was included in the transfection the basal activity of the c-Jun activation domain was stimulated threefold. No enhancement of trans-activation was seen when a vector encoding JNK1 or the nonactivatable mutants of JNK1 and JNK2, JNK1 (APF) and JNK2 (APF), were included in the transfections (Fig. 6B). The enhancing effect of JNK2 was dependent on phosphorylation of the c-Jun activation domain, because the activity of a GAL4-c-Jun (1223; Ala 63/73) construct, encoding a phosphorylation site-defective version of the c-Jun activation domain (Smeal et al. 1991), was not enhanced. The basal activity of GAL4-c-Jun (1-223; Ala 63/73) was similar to that of GAL4-c-Jun (1-223). All of the different JNK proteins (wild type and mutant) were expressed at similar levels (Fig. 6C; Dérijard et al. 1994). However, the JNK1(APF) and INK2(APF) mutants were completely inactive, whereas the TJ-1 mutant had $5 \%$ of wild-type JNK2 activity (data not shown).

\section{Discussion}

Biochemical characterization of JNK activity identified two distinct polypeptides, $46 \mathrm{kD}$ and $55 \mathrm{kD}$ in size, that phosphorylate the amino-terminal sites of c-Jun (Hibi et al. 1993). Both the 46-kD JNK1 (Dérijard et al. 1994) and the $55-\mathrm{kD}$ JNK2 are members of the MAP kinase group. Whereas the two JNKs display $39-43 \%$ sequence identity to other MAP kinases, such as ERK2, they are $83 \%$ identical to each other. While this manuscript was in preparation, cDNAs encoding four JNK related proteins isolated from a rat brain cDNA library were described (Kyriakis et al. 1994). One of these enzymes, SAPKy, appears to be the rat homolog of JNK1, and SAPKaII is most similar to JNK2. Together, these enzymes define a new subgroup of MAP kinases that share the Thr-ProTyr sequence, which harbors their activating phosphorylation sites (Dérijard et al. 1994), suggesting a common activation pathway. This sequence is equivalent to the Thr-Glu-Tyr sequence, which contains the activating phosphorylation sites of ERK1 and ERK2 (Ahn et al. 1992). The two JNKs are activated by diverse extracellular stimuli, including UV irradiation, protein synthesis inhibitors, cytokines, growth factors, and T-cell activators. So far no differences in the regulation of JNKI and JNK2 have been detected. Although the regulation of individual SAPKs was not examined, studies with a polyclonal antiserum that recognizes all forms suggest that their collective activity is regulated similarly to JNK (Kyriakis et al. 1994). The similarity in regulation of JNK1 and JNK2 suggests that they have overlapping functions in the transduction of environmental signals to the transcriptional machinery, a function similar to those of other MAP kinases (Davis 1993; Ammerer 1994). However, despite the highly similar structure and essentially identical regulation, the two JNKs 
Figure 6. Effect of wild-type and mutant INK1 and INK2 on c-jun and Gal4 promoter activities. (A) Jurkat cells were cotransfected with $5 \mu \mathrm{g}$ of either -79junLUC or ACT-LUC reporters and $1 \mu \mathrm{g}$ of $A C T-\beta G a l$, as an internal control, together with $0.5 \mu \mathrm{g}$ of the indicated JNK1 and JNK2 expression vectors or an empty expression vector. Thirty hours after transfection the cells were stimulated with $10 \mathrm{ng} / \mathrm{ml}$ of TPA and, $10 \mathrm{hr}$ later, harvested for measuring luciferase and $\beta$-galactosidase activities. Luciferase activity was normalized relative to $\beta$-galactosidase activity, and the level of expression in cells cotransfected with the empty vector was given a relative value of 1.0. This value represents threefold induction of -79jun-LUC by TPA above basal level. The values shown represent the averages of two separate experiments. $(B)$ HeLa cells were cotransfected with $1.5 \mu \mathrm{g}$ of GAL4-LUC, $0.1 \mu \mathrm{g}$ of GAL4-c-Jun (wt), $0.1 \mu \mathrm{g}$ of GAL4-c-Jun (Ala-63/73), $1 \mu \mathrm{g}$ of ACT-BGal, and $0.25 \mu \mathrm{g}$ of the indicated JNK1 and JNK2 expression vectors or empty expression vector. The cells were harvested, and the data were processed as described in $A .(C)$ Wild-type and mutant INKs are expressed with similar efficiencies. Equal numbers of Jurkat cells transfected with the different INK expression vectors were lysed in SDS sample buffer. The lysates were separated by SDS-PAGE, transferred to Immobilon P membrane, and analyzed by Western blotting with anti-HA antibody and the ECL detection system.

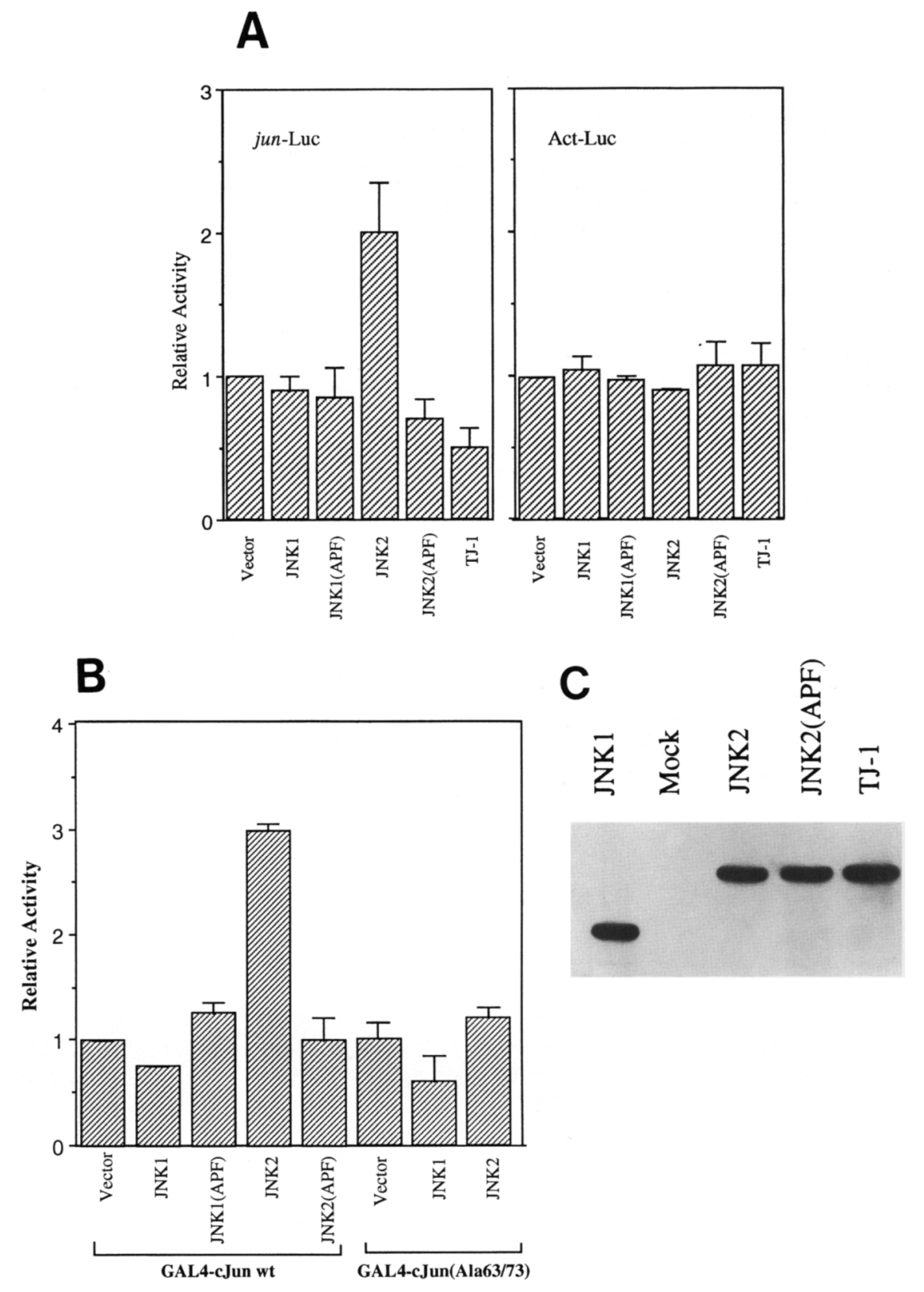

are considerably different in their ability to bind and phosphorylate c-Jun.

In vitro, JNK2 displays a considerably lower $K_{\mathrm{m}}$ toward c-Jun than JNK1 does. This is consistent with its more efficient binding to GST-c-Jun beads. Both efficient c-Jun binding and c-Jun phosphorylation are determined by a short solvent-exposed region on the catalytic carboxy-terminal lobe of the enzyme, which differs between JNK2 and JNK1. These results suggest that at low substrate concentrations, as probably exist in vivo, JNK2 is more likely to phosphorylate c-Jun than is JNK1. Previously, we estimated that most cells contain 100010,000 molecules of AP-1. Using a nuclear diameter of 5 $\mu \mathrm{m}$ and an upper limit of 10,000 c-Jun molecules per nucleus, we obtain a concentration of $260 \mathrm{~nm}$. This con- centration is much lower than the $K_{\mathrm{m}}$ of INKl toward c-Jun and is within the range where JNK2 phosphorylated c-Jun three- to fourfold more efficiently than INK1, in vitro. These assumptions are supported by cotransfection experiments. Cotransfection with a JNK2 expression vector potentiated activation of the c-Jun-responsive c-jun promoter, whereas cotransfection of a JNK1 expression vector had no effect on c-jun promoter activity. Similar results were obtained by using a more specific GAL4 responsive reporter recognized by a GAL4-cJun fusion protein, containing the c-Jun activation domain, whose activity was stimulated threefold by JNK2 but not by JNK1. Little or no inhibition, however, was observed upon cotransfection of inactivated JNK2 mutants. The reason for the limited effects of the wild-type 
and kinase-defective JNK2 on promoter activity is a combination of the relatively higher level of JNK expression than c-Jun expression and the transient nature of the c-Jun:JNK interaction. So far no stable c-Jun:JNK complexes have been isolated from cell lysates.

Differential substrate recognition is an important property that can explain the multitude of MAP kinases and their biological functions. Most cell types coexpress both ERK1 and ERK2, which are highly similar to each other in both structure and regulation (Boulton et al. 1990, 1991). Yet no differences in the ability of ERK1 and ERK2 to recognize specific substrates have been described so far. As discussed below, this may be attributable to the presence of identical residues in their putative specificity determining region. On the other hand, differential substrate recognition is strongly implied by genetic analysis of two other MAP kinases, FUS3 and KSS1, in Saccharomyces cerevisiae (Elion et al. 1990). Although these enzymes are highly similar in their structure and response to pheromones, only some of their functions overlap and KSSI cannot fully substitute for FUS3 (Kurian 1992). Other MAP kinases in yeast have totally different functions (Ammerer 1994). As shown recently, the unique activities of FUS3 may be mediated by its ability to specifically interact with a particular set of substrates (Elion et al. 1993). It is expected, but not yet demonstrated, that KSS1 would be able to interact with only a subset of these substrates. Such differential interactions, as demonstrated for the two JNKs, are likely to play critical roles in conferring biological specificity to the actions of protein kinases that respond to either similar or distinct extracellular stimuli.

Using a series of JNK1/JNK2 chimeras, the structural basis for the higher affinity of JNK2 toward c-Jun was determined. As we have shown, a short $\beta$-strand-like region, composed of a part of kinase domain IX and the sequence between domains IX and X, is largely responsible for increasing the efficiency of the JNK-c-Jun interaction. This region appears to interact with the JNKbinding site between amino acids 30-60 of c-Jun (Hibi et al. 1993). Interestingly, a part of the sequence of this short region is unique to JNK2 and its rat homolog SAPK $\alpha I$ and is variable among all known MAP kinases, with the exception of ERK1 and ERK2. Although, with the exception of the ERKs, no two MAP kinases share fully identical sequences in this region, most of the residues in which JNK1 differs most dramatically from the corresponding JNK2 sequence are well conserved among most family members (Fig. 5C). When switched to the corresponding JNK2 sequence, the resultant JNK1 mu$\operatorname{tant}(J 1 / J 2 / / 1 \mathrm{Na} / \mathrm{Bc}$; Fig. 4) binds c-Jun and phosphorylates it very efficiently. Therefore, it is tempting to speculate that the same region is involved in conferring substrate selectivity in other MAP kinases. According to a three-dimensional model of JNK2, based on the structures of three other protein kinases, including ERK2, we suggest that this specificity-determining region may form an exposed shelf-like structure that is located next to the catalytic site of the enzyme. We suggest that the region forms a docking site recognized by the INK-bind- ing site of c-Jun, attracting c-Jun to the vicinity of the catalytic pocket of JNK2. This increases the likelihood that the phosphoaccepting peptide loops of c-Jun will interact with the catalytic pocket of JNK2. This suggestion is consistent with the kinetic analysis of c-Jun phosphorylation by the JNKs. As shown in Figure 3, JNK2 has a considerably lower $K_{\mathrm{m}}$ toward c-Jun as a substrate than JNKl does. Both kinases, however, are similar in their ability to phosphorylate a substrate with which they fail to form a complex detectable by our in vitro binding assay. The bipartite interaction between a protein kinase and its substrate increases the selectivity of the recognition process by a significant factor and can explain why MAP kinases have distinct substrate specificities even though the primary structures of their phosphoacceptor sites are quite similar to each other. These results provide a molecular framework for understanding the basis for the different biological functions of closely related MAP kinases.

\section{Materials and methods}

\section{Recombinant DNAs}

A human T-cell Jurkat cDNA library (Stratagene) was screened using a full-length JNK I cDNA (Dérijard et al. 1994) as a probe, and a $3.3 \mathrm{~kb}$ clone was obtained, whose nucleotide sequence revealed a high homology to JNK1 cDNA. No other clones exhibiting considerable similarity to $J N K 1$ were found after screening $2 \times 10^{6}$ phages. The JNK2-coding region was fused in its amino terminus to a synthetic oligonucleotide specifying the HA epitope (Wilson et al. 1984). The resulting fragment was subcloned into the pSR $\alpha 3$ expression vector. INK1/JNK2 chimeras were constructed by using a conserved $B c l$ l cleavage site and by introducing $\mathrm{XbaI}, \mathrm{NarI}$, and $\mathrm{Bg} / \mathrm{II}$ cleavage sites present in the JNK2 cDNA into the JNK1 cDNA using site-directed mutagenesis. JNK2 mutants were generated by PCR and were confirmed by DNA sequencing as described (Dérijard et al. 1994). -79jun-LUC, ACT-LUC, and GAL4 constructs were described earlier (Hibi et al. 1993; Su et al. 1994). ACT- $\beta$ Gal contains the $\beta$-galactosidase reporter gene under control of the same $\beta$-actin promoter. The GSTc-Jun constructs have been described previously (Hibi et al. 1993).

\section{Hybridization analyses}

Southern blot analysis was performed as described earlier (Dérijard et al. 1994). Hybridization was performed at $65^{\circ} \mathrm{C}$ for $16 \mathrm{hr}$ with full-length JNK1 and JNK2 cDNA probes. Northern blot analysis was carried out by standard protocols using the fulllength JNK2 cDNA as a probe and hybridization for $16 \mathrm{hr}$ at $65^{\circ} \mathrm{C}$. After hybridization the membranes were washed extensively at $65^{\circ} \mathrm{C}$, followed by autoradiography.

Western blot analysis was done according to standard procedures (Dérijard et al. 1994) using Immobilon P membranes (Millipore). The membranes were probed with anti-HA antibody, and the immune complexes were visualized by the ECL detection system (Amersham) and quantitated using a Molecular Imager GS-250 (Bio-Rad).

\section{Transfections}

Jurkat $\mathrm{T}$ antigen cells (a gift from Dr. G. Crabtree, Stanford University, CA) were grown and transfected as described (Su et 
al. 1994). HeLa S3 and COS 1 cells were maintained in Dulbecco's modified Eagle medium supplemented with $10 \%$ fetal calf serum and transfected using lipofectamine (GIBCO-BRL). For immune complex kinase assays, cells were harvested $20 \mathrm{~min}$ following the different treatments, and for luciferase assays 10 $\mathrm{hr}$ after the treatments. Normally, all assays were done $40 \mathrm{hr}$ after the initial transfection.

\section{Immunoprecipitations}

The cells were lysed in $20 \mathrm{~mm}$ Tris- $\mathrm{HCl}$ (pH 7.7), $250 \mathrm{mM} \mathrm{NaCl}$, $3 \mathrm{~mm}$ EDTA, $3 \mathrm{~mm}$ EGTA, 0.5\% NP-40, $1 \mathrm{~mm} p$-nitrophenylphosphate (PNPP), $10 \mathrm{mM} \beta$-glycerophosphate, and $100 \mu \mathrm{M}$ $\mathrm{Na}$-vanadate in the presence of proteinase inhibitors. The cell debris was spun down, the lysates were precleaned, and the recombinant proteins were precipitated with monoclonal antiHA antibody (Boehringer Mannheim) or affinity purified monoclonal anti-CD3 antibody OKT3, together with protein A-Sepharose as described (Dérijard et al. 1994).

\section{Protein purification, binding, and kinase assays}

GST-fusion proteins were purified, and JNK binding to c-Jun was assayed as described (Hibi et al. 1993; Dérijard et al. 1994). The amounts of cell extracts loaded onto the columns were normalized by Western blotting and ECL detection using a Molecular Imager (Bio-Rad) to contain equal amounts of HA-JNK1 and HA-JNK2. The total amount of protein was adjusted with extracts of mock transfected cells. GSTc-Jun(1-79) beads were incubated at $4^{\circ} \mathrm{C}$ for $12 \mathrm{hr}$ with cell extracts followed by seven washes with lysis buffer containing $0.05 \%$ Tween 20 instead of NP-40. The proteins were eluted in SDS-PAGE loading buffer, separated by SDS-PAGE, transferred to a nylon membrane, immunoblotted with anti-HA antibody, visualized by ECL, and quantitated on a Molecular Imager (Bio-Rad) using a chemiluminescence screen.

Immune complex kinase assays were performed in $30 \mu \mathrm{l}$ of kinase buffer consisting of $20 \mathrm{~mm}$ HEPES at $\mathrm{pH} 7.6,2 \mathrm{~mm}$ DTT, $10 \mathrm{~mm} \mathrm{MgCl} 2,1 \mathrm{~mm}$ EDTA, $1 \mathrm{~mm}$ EGTA, $1 \mathrm{~mm}$ PNPP, $10 \mathrm{~mm}$ $\beta$-glycerophosphate and $100 \mu \mathrm{M} \mathrm{Na}$-vanadate, and $1 \mu \mathrm{M}$ of ATP supplemented with $10 \mu \mathrm{Ci}$ of $\left[\gamma^{-32} \mathrm{P}\right] \mathrm{ATP}$. To compare the kinetics of JNK1- and JNK2-catalyzed c-Jun phosphorylation, lysates from several HA-JNK1 and HA-JNK2 transfections were pooled, and after the immunoprecipitations and extensive washings the antibody-antigen complexes were disrupted by incubating them with 100 -fold molar excess of HA-peptide in kinase buffer in the presence of $0.2 \mathrm{mg} / \mu \mathrm{l}$ of bovine serum albumin for $16 \mathrm{hr}$ at $4^{\circ} \mathrm{C}$. According to our pilot experiments, both albumin and HA-peptide when used in the above concentrations do not have any effect on kinase activity. The amounts of the eluted HA-JNK fusion proteins used in the phosphorylation reactions were adjusted following determination of their relative concentrations by Western blot analysis. Equal amounts of HA-JNK1 and HA-JNK2 were incubated with various amounts of GST c-Jun(1-79) for $10 \mathrm{~min}$ in kinase buffer. The kinase reactions were initiated by adding ATP and terminated by addition of SDS-PAGE sample buffer. Reaction rates were determined as the amount of phosphate incorporated versus reaction time (usually $10 \mathrm{~min}$; the reactions were linear for $30 \mathrm{~min}$ ). The phosphorylated GSTc-Jun bands were cut out after separation by SDS-PAGE and quantitated by liquid scintillation.

The in-gel kinase assay was done as described (Hibi et al 1993) using GSTc-Jun(1-79) as a substrate. The incorporation of phosphate was detected by autoradiography and quantitated with a PhosphorImager and ImageQuant software (Molecular Dynamics).

\section{Molecular modeling}

The JNK2 model was created using Silicon Graphic Indigo Station and the Homology program (Biosym, 1994). The structure of all insertions was constructed using the "Fragment Generator" Homology program. The side chains of JNK2 model were then minimized using the Discover program (Biosym, 1994) for 2000 interactions with steepest descents algorithm.

\section{Acknowledgments}

We thank Masahiko Hibi for helpful discussion, advice, and reagents, Susan Taylor for advice and support, Sung Hou Kim and Elizabeth Goldsmith for generously providing the CDK2 and ERK2 coordinates, Susan Taylor for comparison with PKA, Tony Hunter for critical comments on the manuscript, Katsuji Yoshioka for RNA samples, Dou Liu for DNA samples, Tiliang Deng for the HA-expression vector, and Scherita Hill for preparation of this manuscript. T.K. was partially supported by a postdoctoral fellowship from the Finnish Academy of Science; B.S. was supported by a fellowship from the Irvington Institute. Work in M.K.'s laboratory was supported by the National Institutes of Health, Department of Energy and the Council for Tobacco Research. I.T. was supported in part by an American Cancer Society grant to Susan Taylor.

The publication costs of this article were defrayed in part by payment of page charges. This article must therefore be hereby marked "advertisement" in accordance with 18 USC section 1734 solely to indicate this fact.

\section{References}

Ahn, N.G., R. Seger, and E.G. Krebs. 1992. The mitogen-activated protein kinase activator. Curr. Opin. Cell Biol. 4: 992999.

Alvarez, E., I.C. Northwood, F.A. Gonzalez, D.A. Latour, A. Seth, C. Abate, T. Curran, and R.J. Davis. 1991. Pro-Leu-Ser/ Thr-Pro is a consensus primary sequence for substrate protein phosphorylation. Characterization of the phosphorylation of c-myc and c-jun proteins by an epidermal growth factor receptor threonine 669 protein kinase. I. Biol. Chem. 226: $15277-15285$.

Ammerer, G. 1994. Sex, stress and integrity: the importance of MAP kinases in yeast. Curr. Opin. Genes Dev. 4: 90-95.

Angel, P., K. Hattori, T. Smeal, and M. Karin. 1988. The jun proto-oncogene is positively autoregulated by its product, Jun/AP-1. Cell 55: 875-885.

Binétruy, B., T. Smeal, and M. Karin. 1991. H-Ras augments c-Jun activity and stimulates phosphorylation of its activation domain. Nature 351: 122-127.

Boulton, T.G., G.D. Yancopoulos, J.S. Gregory, C. Slaughter, C. Moomaw, J. Hsu, and M.H. Cobb. 1990. An insulin-stimulated protein kinase similar to yeast kinases involved in cell cycle control. Science 249: 64-67.

Boulton, T.G., S.H. Nye, D.J. Robbins, N.Y. Ip, E. Radziejewska, S.D. Morgenbesser, R.A. DePinho, N. Panayotatos, M.H. Cobb, and G.D. Yancopoulos. 1991. ERKs: A family of protein-serine/threonine kinases that are activated and tyrosine phosphorylated in response to insulin and NGF. Cell 65: 663-675.

Boyle, W.J., P. van der Greer, and T. Hunter. 1991. Phosphopeptide mapping and phosphoamino acid analysis by two-di- 
mensional separation on thin layer cellulose plates. Methods Enzymol. 201: 110-149.

Brunner, D., N. Oellers, J. Szabad, W.H. Biggs III, S.L. Zipursky, and E. Hafen. 1994. A gain-of-function mutation in Drosophila MAP kinase activates multiple receptor tyrosine kinase signaling pathways. Cell 76: 875-888.

Cano, E., C.A. Hazzalin, and L.C. Mahadevan. 1994. Anisomycin-activated protein kinases $\mathrm{p} 45$ and p55 but not mitogenactivated protein kinases ERK-1 and -2 are implicated in the induction of c-fos and c-jun. Mol. Cell. Biol. 14: 7352-7362.

Davis, R.J. 1993. The mitogen-activated protein kinase signal transduction pathway. I. Biol. Chem. 268: 14553-14556.

De Bondt, H.L., J. Rosenblatt, J. Jancarik, H.D. Jones, D.O. Morgan, and S.-H. Kim. 1993. Crystal structure of cyclin-dependent kinase 2. Nature 363: 595-602.

Dérijard, B., M. Hibi, I.H. Wu, T. Barrett, B. Su, T. Deng, M. Karin, and R.J. Davis. 1994. JNK1: A protein kinase stimulated by UV light and Ha-Ras that binds and phosphorylates the c-Jun activation domain. Cell 76: 1025-1037.

Devary, Y., R.A. Gottlieb, T. Smeal, and M. Karin. 1992. The mammalian ultraviolet response is triggered by activation of Src tyrosine kinases. Cell 71: 1081-1091.

Edwards, D.R. and L.C. Mahadevan. 1992. Protein synthesis inhibitors differentially superinduce $c$-fos and $c$-jun by three distinct mechanism: lack of evidence for labile repressors. EMBO J. 11(7): 2415-2424.

Elion, E.A., P.L. Grisafi, and G.R. Fink. 1990. FUS3 encodes a cdc2 $+/ C D C 28$-related kinase required for the transition from mitosis into conjugation. Cell 60: 649-664.

Elion, E.A., B. Satterberg, and J.E. Kranz. 1993. FUS3 phosphorylated multiple components of the mating signal transduction cascade: Evidence for STE12 and FAR1. Mol. Biol. Cell 4: $495-510$

Gupta, S., D. Campbell, B. Dérijard, and R.J. Davis. 1994. Transcription factor ATF2 is regulated by the c-Jun $\mathrm{NH}_{2}$-terminal kinase (JNK) signal transduction pathway. Science (in press).

Hanks, S.K., A.M. Quinn, and T. Hunter. 1988. The protein kinase family: conserved features and deduced phylogeny of the catalytic domains. Science 241: 42-52.

Hibi, M., A. Lin, T. Smeal, A. Minden, and M. Karin. 1993. Identification of an oncoprotein- and UV-responsive protein kinase that binds and potentiates the c-Jun activation domain. Genes \& Dev. 7: 2135-2148

Kameshita, E. and H. Fujisawa. 1989. A sensitive method for detection of calmodulin-dependent protein kinase II activity in sodium dodecyl sulfate-polyacrylamide gel. Anal. Biochem. 183: 139-143.

Karin, M. 1994. Signal transduction from the cell surface to the nucleus through the phosphorylation of transcription factors. Curr. Opin. Cell Biol. 6: 415-424.

Kurjan, J. 1992. Pheromone response in yeast. Annu. Rev. Biochem. 61: 1097-1129.

Kyriakis, J.M., P. Banerjee, E. Nikolakaki, T. Dai, E.A. Rubie, M.F. Ahmad, J. Avruch, and J.R. Woodgett. 1994. The stressactivated protein kinase subfamily of c-Jun kinases. Nature 369: 156-160.

Minden, A., A. Lin, T. Smeal, M. Dérijard, M. Cobb, R. Davis, and M. Karin. 1994. c-Jun N-terminal phosphorylation correlates with activation of the JNK, and not the ERK, subgroup of mitogen-activated protein kinases. Mol. Cell. Biol. 14: 6683-6688.

O'Neill, E.M., I. Rebay, R. Tjian, and G.M. Rubin. 1994. The activities of two Ets-related transcription factors required for Drosophila eye development are modulated by the Ras/ MAPK pathway. Cell 78: 137-147.

Pulverer, B.J., J.M. Kyriakis, J. Avruch, E. Nikolakaki, and J.R.
Woodgett. 1991. Phosphorylation of c-jun mediated by MAP kinases. Nature 353: 670-674.

Smeal, T., R. Binétruy, D.A. Mercola, M. Birrer, and M. Karin. 1991. Oncogenic and transcriptional cooperation with HaRas requires phosphorylation of c-Jun on serines 63 and 73 Nature 354: 494-496.

Smeal, T., B. Binétruy, D. Mercola, A. Grover-Bardwick, G. Heidecker, U.R. Rapp, and M. Karin. 1992. Oncoprotein-mediated signalling cascade stimulates c-Jun activity by phosphorylation of serines 63 and 73. Mol. Cell. Biol. 12: 35073513.

Su, B., E. Jacinto, M. Hibi, T. Kallunki, M. Karin, and Y. BenNeriah. 1994. JNK is involved in signal integration during costimulation of $\mathrm{T}$ lymphocytes. Cell 77: 727-736.

van Dam, H., M. Duyndam, R. Rottier, A. Bosch, L. de VriesSmits, P. Herrlich, A. Zantema, P. Angel, and A.J. van der Eb. 1993. Heterodimer formation of cJun and ATF-2 is responsible for induction of $\mathrm{c}$-jun by the 243 amino acid adenovirus ElA protein. EMBO I. 12: 479-487.

Wilson, I.A., H.L. Niman, R.A. Houghten, A.R. Cherenson, M.L. Connolly, and R.A. Lerner. 1984. The structure of an antigenic determinant in a protein. Cell 37: 767-778.

Zhang, F., A. Strand, D. Robbins, M.H. Cobb, and E.J. Goldsmith. 1994. Atomic structure of the MAP kinase ERK2 at $2.3 \AA$ resolution. Nature 367: 704-711.

Zheng, J., D.R. Knighton, L.F. ten Eyck, R. Karlsson, N. Xuong, S.S. Taylor, and J.M. Sowadski. 1993. Crystal structure of the catalytic subunit of cAMP-dependent protein kinase complexed with MgATP and peptide inhibitor. Biochemistry 32: 2154-2161. 


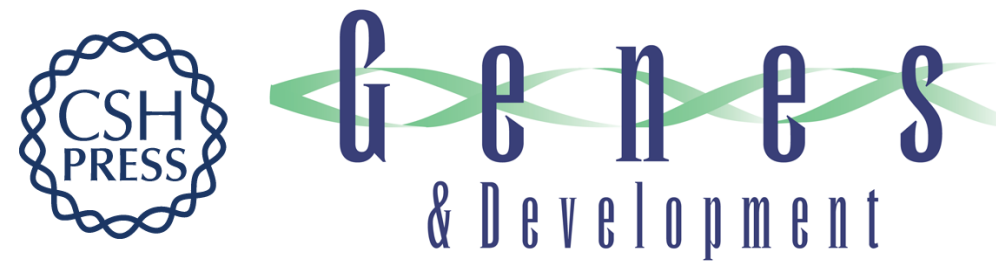

\section{JNK2 contains a specificity-determining region responsible for efficient C-Jun binding and phosphorylation.}

T Kallunki, B Su, I Tsigelny, et al.

Genes Dev. 1994, 8:

Access the most recent version at doi:10.1101/gad.8.24.2996

References This article cites 33 articles, 8 of which can be accessed free at:

http://genesdev.cshlp.org/content/8/24/2996.full.html\#ref-list-1

License

Email Alerting

Service

Receive free email alerts when new articles cite this article - sign up in the box at the top right corner of the article or click here.

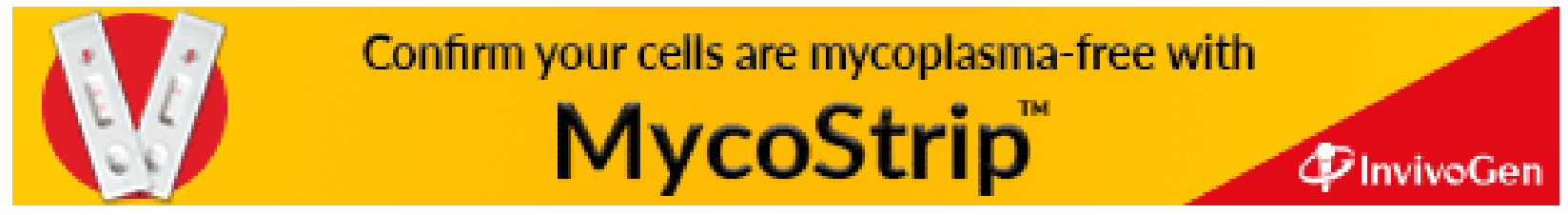

